\title{
Lipogenesis in Human Adipose Tissue: Some Effects of Nibbling and Gorging
}

\author{
George A. Bray \\ From the Departments of Medicine, New England Medical Center Hospitals \\ and Tufts University, School of Medicine, Boston, Massachusetts 02111, \\ and the Departments of Medicine, University of California at Los Angeles \\ and Harbor General Hospital, Torrance, California 90509
}

\begin{abstract}
A в STRACT Six grossly obese patients were fed 5000 calorie diets for $4 \mathrm{wk}$. During one period of 2 wk, the calories were consumed over $4 \mathrm{hr}$ (gorging) and during the other 2 wk, the dietary intake was spread over $20 \mathrm{hr}$ (nibbling). Each of these periods followed a low caloric intake which lasted at least 10 days. Three male patients (group I) were studied at or near their maximal weight and three females (group II) after a weight loss of 50-70 kg. The patients in group II gained more weight than those in group I. Lipogenesis from pyruvate was greater in group II than in group I. Rapid ingestion of food (gorging) was accompanied by a significant increase in glycerideglycerol- ${ }^{14} \mathrm{C}$ and fatty acids- ${ }^{14} \mathrm{C}$ from pyruvate $-{ }^{14} \mathrm{C}$. The enzymatic activity of sn-glycerol 3-phosphate dehydrogenase and mitochondrial glycerophosphate oxidase paralleled the rate of formation of glyceride-glycerol. Lipogenesis from pyruvate was significantly lower when the bicarbonate concentration was reduced from 25 to $10 \mathrm{~mm}$. Citrate and acetate were also converted to fatty acids but there was no difference between gorging and nibbling. An inhibitor of carbonic anhydrase significantly reduced the conversion of pyruvate into $\mathrm{CO}_{2}$, glyceride-glycerol, and fatty acids. These data on gorging and nibbling have been related to other studies suggesting that the frequency of food intake may be inversely related to obesity.
\end{abstract}

\section{INTRODUCTION}

Although the rat is normally a nocturnal animal and eats small meals several time during the day (nibbling), it can be trained to eat over a short period of time (meal-eating or gorging) (1-3). Comparing rats trained to gorge with normal nibbling rats has revealed

Received for publication 9 August 1971 and in revised form 18 October 1971. a number of significant metabolic changes (1-4). Mealeating rats consume less food and are usually smaller than nibbling controls (2) although they may become heavier (5). The percentage of total body fat is increased by meal-eating whether or not the rats are heavier (1-4). Moreover, the availability of food for a short period each day will induce a number of metabolic adaptations in adipose tissue and liver which favor the rapid storage of the ingested food as glycogen or fat $(1-4)$. These adaptations have been referred to as "adaptive hyperlipogenesis" (4). The findings in rats have been extrapolated to the human as an explanation for the nocturnal eating pattern (6) which is often associated with excess weight. Fabry, Fodor, Hejl, Braun, and Zvolankova have found, for example, that individuals consuming a few large meals tend to be obese, whereas lean subjects tend to eat more frequently (7). To date there are no reported studies on variations in the pattern of food intake on the metabolism of the human adipose tissue. Our finding that a high caloric intake was associated with incorporation of carbon from glucose and pyruvate in fatty acids (8) made it possible to examine the effects of varying the duration of food ingestion of obese subjects on a high caloric intake. The results of these studies are reported below.

\section{METHODS}

Six grossly obese patients were studied while hospitalized on the Clinical Study Unit of the New England Medical Center Hospitals (Table I). They have been divided into two groups which differ in several respects. In the first group, all subjects were males and were studied at or near their maximal weight. The second group were all females and were studied at the end of a weight reduction of $50-70 \mathrm{~kg}$. The weight gained during overeating ranged between 1.1 and $2.4 \mathrm{~kg}$ for group I and between 3.5 and 13.8 $\mathrm{kg}$ for group II. The ages were lower in the second group than in the first group. Finally, two of the subjects in the 
TABLE I

Clinical Data

\begin{tabular}{|c|c|c|c|c|c|c|c|c|}
\hline \multirow[b]{2}{*}{ Patient } & \multirow[b]{2}{*}{ Age } & \multirow[b]{2}{*}{ Sex } & \multicolumn{3}{|c|}{ Body weight } & \multirow[b]{2}{*}{ Calories } & \multirow{2}{*}{$\begin{array}{c}\text { Dura- } \\
\text { tion }\end{array}$} & \multirow{2}{*}{$\begin{array}{l}\text { Carbo- } \\
\text { hydrate }\end{array}$} \\
\hline & & & Initial & Final & Diff. & & & \\
\hline & $y r$ & & & $k g$ & & kcal & days & $\%$ \\
\hline \multicolumn{9}{|l|}{ Group I } \\
\hline \multirow[t]{2}{*}{ W. H. } & 41 & $\mathbf{M}$ & 245.2 & 246.3 & 1.1 & $4000 \mathrm{G}^{*}$ & 21 & 50 \\
\hline & & & 225.3 & 226.5 & 1.2 & $5000 \mathrm{~N}^{*}$ & 14 & 50 \\
\hline \multirow[t]{2}{*}{ T. K. } & 42 & $\mathbf{M}$ & 143.9 & 146.1 & 2.2 & $5000 \mathrm{~N}$ & 14 & 50 \\
\hline & & & 139.7 & 141.6 & 1.9 & $5000 \mathrm{G}$ & 15 & 50 \\
\hline \multirow[t]{2}{*}{ R. J. } & 25 & $\mathbf{M}$ & 157.5 & 159.9 & 2.4 & $5000 \mathrm{G}$ & 15 & 75 \\
\hline & & & 147.6 & 150.3 & 2.7 & $5000 \mathrm{~N}$ & 14 & 75 \\
\hline \multicolumn{9}{|l|}{ Group II } \\
\hline \multirow[t]{2}{*}{ D. D. } & 22 & $\mathrm{~F}$ & 118.4 & 131.6 & 13.8 & $5000 \mathrm{~N}$ & 14 & 75 \\
\hline & & & 120.4 & 130.3 & 9.9 & $5000 \mathrm{G}$ & 14 & 75 \\
\hline \multirow[t]{2}{*}{ L. M. } & 21 & $\mathrm{~F}$ & 98.1 & 103.3 & +5.2 & $5000 \mathrm{~N}$ & 14 & 75 \\
\hline & & & 96.2 & 100.3 & +4.1 & $5000 \mathrm{G}$ & 14 & 75 \\
\hline \multirow[t]{2}{*}{ M. D. } & 21 & $\mathrm{~F}$ & 112.5 & 116.0 & 3.5 & $5000 \mathrm{G}$ & 14 & 75 \\
\hline & & & 111.5 & 115.1 & 3.6 & $5000 \mathrm{~N}$ & 14 & 75 \\
\hline
\end{tabular}

* $\mathrm{G}$, gorging regimen; $\mathrm{N}$, nibbling regimen (see text).

first group received a lower carbohydrate intake than those in group II.

Each patient was fed two diets for a period of 14 or 15 days with the exception of the first study on $W . H$. where one diet was fed for 21 days and the other for 14 days. In all studies except the first, 5000 calories of a high carbohydrate liquid diet were fed. For the first two patients in group I, the carbohydrate content was $50 \%$ of the total calories, but in the remaining four studies, carbohydrate provided $75 \%$ of the total calories. Two of the three studies in each group were conducted with the nibbling period first because it proved easier to begin patients with the nibbling regimen than on the gorging regimen. All patients had been on a total fast or 450 calorie diet for at least ten days before beginning the high caloric intake. While gorging, the high caloric diet was fed in a $4 \mathrm{hr}$ period between 6 and 10 p.m.; while nibbling, the patients received 10 equal feedings at $2 \mathrm{hr}$ intervals between $6 \mathrm{a} . \mathrm{m}$. and 12 p.m. Stools were collected over 6 days from four patients while gorging and again while nibbling. Two pools of 3 days each were homogenized and a portion freezedried. The caloric content of samples of stool were determined in a Parr bomb calorimeter (Parr Instrument Co., Moline, Ill.). At the end of each dietary period, the pa-

TABLE II

Protocol for Comparing Bicarbonate and $\mathrm{PcO}_{2}$

\begin{tabular}{cccc}
\hline & \multicolumn{3}{c}{$\mathrm{PcO}_{2}, \mathrm{~mm} \mathrm{Hg}$} \\
\cline { 2 - 5 } $\begin{array}{c}\text { Bicar- } \\
\text { bonate }\end{array}$ & $\mathbf{4 0}$ & 30 & 20 \\
\hline$m M$ & \multicolumn{4}{c}{$p H$} \\
25 & 7.40 & 7.54 & 7.71 \\
20 & 7.32 & 7.45 & 7.62 \\
15 & 7.20 & 7.32 & 7.50 \\
10 & 7.02 & 7.14 & 7.32 \\
\hline
\end{tabular}

tients were fasted overnight and a biopsy of subcutaneous fat from the anterior abdominal panniculus was obtained as previously described (8).

Metabolic procedures. The adipose tissue obtained at biopsy was transported to the laboratory at room temperature in $0.15 \mathrm{M}$ saline. Pieces weighing approximately 100 $\pm 10 \mathrm{mg}$ were cut and weighed on a torsion balance. They were placed in vials containing $1 \mathrm{ml}$ of Krebs-Ringer bicarbonate buffer, gassed with the appropriate mixture (usually $95 \%$ oxygen and $5 \% \mathrm{CO}_{2}$ ), and incubated for $3 \mathrm{hr}$. All measurements were carried out in triplicate. For the studies on glucose metabolism, glucose was present in a $2 \mathrm{~mm}$ concentration with $0.05 \mu \mathrm{Ci}$ glucose $-1-{ }^{14} \mathrm{C} / \mathrm{mmole}$. Insulin was prepared by diluting commercially available crystalline insulin (Eli Lilly \& Co., Indianapolis, Ind.) to a concentration of $200 \mu \mathrm{U} / \mathrm{ml}$. The metabolism of pyruvate in vitro was examined in three separate experiments on each biopsy. The first experiment compared the effect of $5 \mathrm{~mm}$ glucose on the metabolism of $5 \mathrm{~mm}$ pyruvate- $3-{ }^{14} \mathrm{C}(0.02 \mu \mathrm{Ci} /$ mmole). For the second experiment the metabolism of pyruvate was studied in the presence of varying concentrations of bicarbonate and $\mathrm{P}_{\mathrm{CO}_{2}}$ as shown in Table II. A $\mathrm{P}_{\mathrm{CO}_{2}}$ of 40,30 , or $20 \mathrm{~mm} \mathrm{Hg}$ (equal to $5 \% \mathrm{CO}_{2}: 95 \% \mathrm{O}_{2}$; $3.75 \% \mathrm{CO}_{2}: 96.25 \% \mathrm{O}_{2}$; and $2.5 \% \mathrm{CO}_{2}: 97.5 \% \mathrm{O}_{2}$, respectively) was used to aerate the medium. The $\mathrm{pH}$ for each $\mathrm{P}_{\mathrm{CO}_{2}}$-bicarbonate concentration was calculated from the Henderson-Hasselbach equation and the albumin buffer was titrated to this $\mathrm{pH}$ before aerating. The third experiment examined the effect of a carbonic anhydrase inhibitor, ethoxzolamide $(25 \mu \mathrm{g} / \mathrm{ml}),{ }^{1}$ on pyruvate metabolism. The bicarbonate concentrations for this experiment were 10 , 15,20 , and $25 \mathrm{~mm}$ and the $\mathrm{P}_{\mathrm{CO}_{2}}$ was $40 \quad\left(5 \% \quad \mathrm{CO}_{2}: 95 \%\right.$ $\mathrm{O}_{2}$ ).

For experiments on the incorporation of radioactivity from citrate and acetate into fatty acids, the incubation

${ }^{1}$ Kindly supplied by Dr. Thomas Maren, University of Florida, College of Medicine, Gainesville, Fla. 
TABLE III

Metabolism of Radioactive Glucose by Adipose Tissue from Obese Subjects*

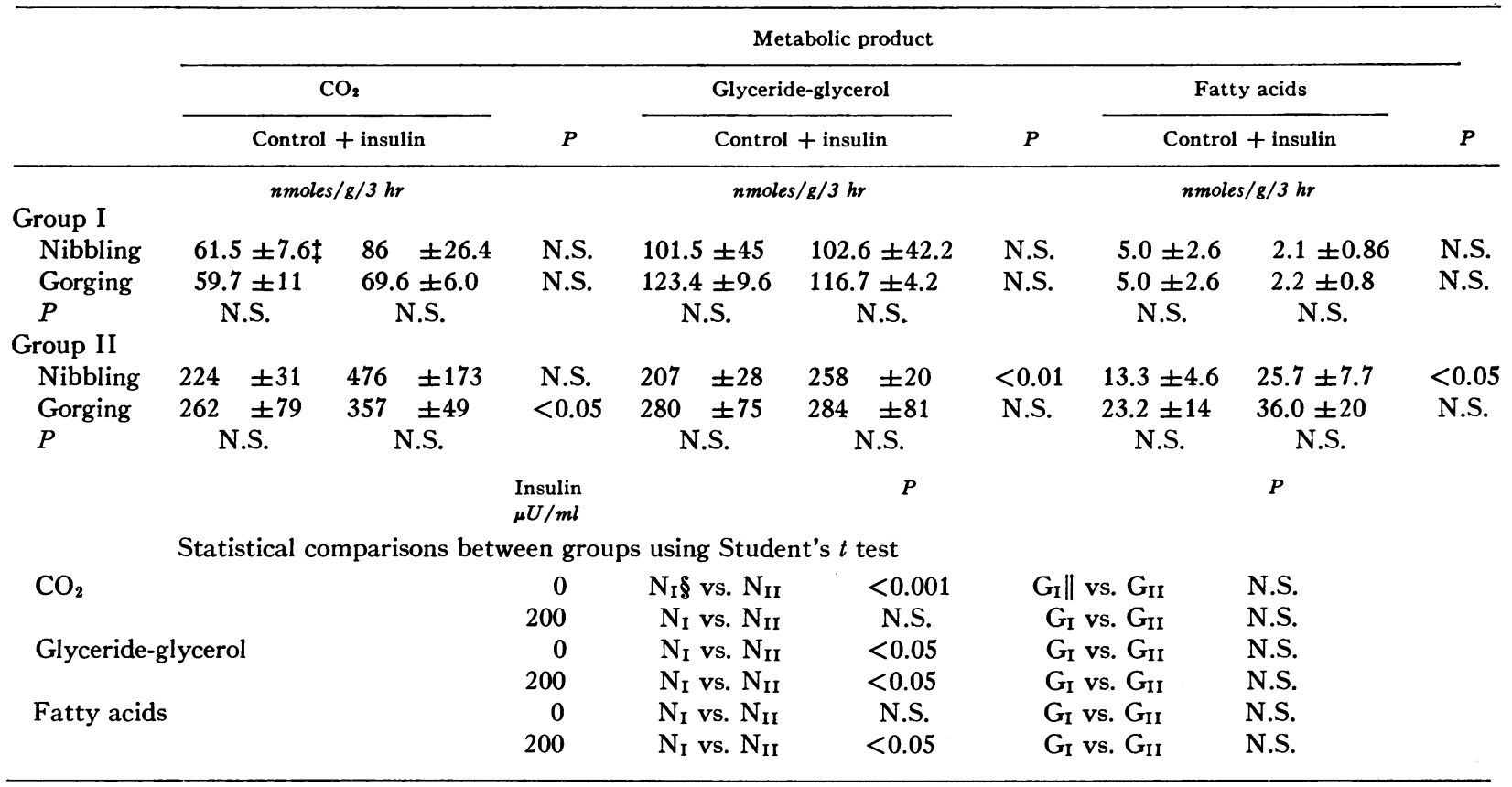

${ }^{*}$ Pieces of fat were incubated in triplicate in Krebs-Ringer bicarbonate buffer containing 2 mM glucose-1-14 $\mathrm{C}$; and albumin $40 \mathrm{mg} / \mathrm{ml}$.

$\ddagger$ Mean \pm SE.

$\S \mathrm{N}$, Nibbling; the subscript I or II represents the group.

$\| \mathrm{G}$, Gorging; the subscript I or II represents the group.

buffer contained $10 \mathrm{~mm}$ citrate- $1,5-{ }^{14} \mathrm{C}(0.01 \mu \mathrm{Ci} / \mu$ mole $)$ or $10 \mathrm{~mm}$ acetate $(0.05 \mu \mathrm{Ci} / \mu$ mole $)$ labeled in the methyl group with tritium. At the end of $3 \mathrm{hr}$ of incubation at $37^{\circ} \mathrm{C}$ with shaking, the vials were removed and chilled on ice. The $\mathrm{CO}_{2}$ evolved during the incubation procedures was released from the medium with $0.5 \mathrm{ml} 0.5 \mathrm{~N} \mathrm{H}_{2} \mathrm{SO}_{4}$ and trapped in $0.5 \mathrm{ml}$ Hyamine (Rohm and Haas Co., Philadelphia, $\mathrm{Pa}$.) added to a plastic cup suspended from the top of the vial. After collecting $\mathrm{CO}_{2}$, the cup containing Hyamine was removed and placed in a counting vial for assay of radioactivity (9). The adipose tissue fragments were then frozen until processed. The adipose tissue was thawed and homogenized in Dole's extraction fluid (10). Heptane and water were added and after removal, the heptane layer was washed repeatedly with $0.2 \mathrm{~N} \mathrm{NaOH}$ to remove pyruvate, citrate, and acetate. After the washes were free of radioactivity, a sample of the heptane layer was counted to determine the radioactivity in "triglyceride." A second sample was removed and hydrolyzed in a $1: 1$ mixture of $95 \%$ ethanol and $1 \mathrm{~N}$ potassium hydroxide at $60^{\circ} \mathrm{C}$. The hydrolysate was acidified and the fatty acids extracted with heptane. The heptane washings were dried and the residue counted for radioactivity. The radioactivity appearing in the glyceride-glycerol was calculated by subtracting the total amount of radioactivity in the fatty acids from the total amount in "triglyceride." Losses due to quenching were corrected by adding an internal standard.

Enzymatic assays. For the enzymatic assays, a piece of adipose tissue from the original biopsy was removed immediately, weighed, and homogenized in 4 volumes of ice cold
$0.25 \mathrm{M}$ sucrose. This homogenate was centrifuged at 700 $1000 \mathrm{~g}$ at $4^{\circ} \mathrm{C}$ for $10 \mathrm{~min}$ and the layer between the fat cake and pellet was removed and used as the "whole homogenate" in most assays. For the determination of mitochondrial glycerophosphate oxidase, a mitochondrial preparation was prepared by centrifuging a sample of the "whole homogenate" at $15,000 \mathrm{~g}$ for $30 \mathrm{~min}$, washing with $0.25 \mathrm{M}$ sucrose and recentrifuging. The assays of sn-glycerol 3phosphate dehydrogenase (E.C. 1.1.1.8), lactate dehydrogenase (E.C. 1.1.1.27), malate dehydrogenase (E.C. 1.1.1.37), glucose-6-phosphate dehydrogenase (E.C. 1.1.1.49) and malic enzyme (E.C. 1.1.1.40) were performed by recording the initial rate of change in optical density of the reduced or oxidized pyridine nucleotides on a Cary model 15 recording spectrophotometer (Cary Instruments, Monrovia, Calif.) (11) after adding substrate. Assays were repeated and the rate of reaction was taken as the initial linear relationship. The mitochondrial glycerophosphate oxidase (E.C. 1.1.2.1) was determined by measuring the transfer of hydrogen to iodinitrotetrozolium as described previously (8). Protein was determined by the biuret method (12) and all enzymatic activities were corrected for the protein content.

Materials. Chemicals were reagent grade and reagents were prepared in glass distilled water. Enzymes were purchased from Boehringer, Mannheim Corp., New York. Radiochemicals were purchased from New England Nuclear Corp., Boston, Mass.

Statistics. The data have been examined by comparing group means using Student's $t$ test and by regression analysis with a program for the Wang desk top calculator 
TABLE IV

Factorial Analysis and Statistical Results

\begin{tabular}{|c|c|c|c|c|c|}
\hline \multicolumn{3}{|c|}{ Data from Table III } & \multicolumn{3}{|c|}{ Data from Table $V$} \\
\hline Factor & Level & $P$ & Factor & Level & $\boldsymbol{P}$ \\
\hline Food_intake & $\begin{array}{l}\text { Nibbling } \\
\text { Gorging }\end{array}$ & N.S. & Food intake & $\begin{array}{l}\text { Nibbling } \\
\text { Gorging }\end{array}$ & N.S. \\
\hline Patients & $\begin{array}{l}\text { Group I } \\
\text { Group II }\end{array}$ & $<0.05$ & Patients & $\begin{array}{l}\text { Group I } \\
\text { Group II }\end{array}$ & $<0.05$ \\
\hline Insulin, $\mu U / m l$ & $\begin{array}{l}0 \\
200\end{array}$ & N.S. & Glucose, $m M$ & $\begin{array}{l}0 \\
5\end{array}$ & N.S. \\
\hline Metabolic product & $\begin{array}{l}\mathrm{CO}_{2} \\
\text { Fatty acids }\end{array}$ & $<0.05$ & Metabolic product & $\begin{array}{l}\text { Glyceride-glycerol } \\
\text { Fatty acids }\end{array}$ & $<0.05$ \\
\hline
\end{tabular}

* This table lists the factors and levels which were used in a $2^{4}$ factorial analysis. The $P$ is for the statistical effects of the main comparisons. Subsidiary interactions were not statistically significant. $\ddagger N \rightarrow G$, Nibbling first; gorging second.

(Wang Laboratories, Inc., Tewksbury, Mass.). Factorial analysis (13) using the Yates method for factors at two levels was applied using a $2^{4}$ table (Table IV).

\section{RESULTS}

Metabolism of glucose. The effects of dietary intake on the metabolism of glucose are seen in Table III. The patients in group II metabolized more glucose than those in group I. This difference ranged between 2.5 and 5 times depending on the product measured. Factorial analysis (Table IV) confirmed this by showing a statistically significant difference (Table III, lower half) between groups I and II and between metabolic products. No differences could be attributed to the pattern of food intake (Table IV). Insulin significantly stimulated carbon incorporation into fatty acids and $\mathrm{CO}_{2}$ in group II when data from periods of nibbling and gorging were compared by $t$ test of paired differences (Table III). The patients in group I, however, showed no significant effects of insulin on formation of $\mathrm{CO}_{2}$ or fatty acids. Since the data from groups I and II were pooled for factorial analysis (Table IV, left hand column), no overall effect of insulin could be demonstrated. Comparisons between subjects M. D. and D. D. in group II and T. K. and R. J. in group I showed no significant effects of the carbohydrate intake or of differences in weight gain. Fecal loss of calories averaged $212 \pm 28 \mathrm{kcal} /$ day during the nibbling period and $475 \pm 14 \mathrm{kcal} / \mathrm{day}$ during gorging. These losses were not significantly different and represented less than $5 \%$ of the intake.

Metabolism of pyruvate. The effects of food intake on the metabolism of pyruvate in vitro are presented in Tables IV and V. Fat from the patients in group II converted over 100 times more radioactivity into fatty acids in the absence of glucose than did fat from patients in group I (Table V, second column from the right). The presence of glucose significantly increased the conversion of pyruvate into fatty acids in three of the four subgroups (Table V, group I, N+G; group II, G). The conversion of radioactivity into glycerideglycerol was also greater by a factor of 8 to 20 in fat from patients in group II as compared with group I. The incorporation of carbon into fatty acids was greater than the quantity oxidized to $\mathrm{CO}_{2}$ in group II, but much less in group I. Factorial analysis of the data in Table $\mathrm{V}$ (see Table IV) showed no statistical differences attributable to the dietary regime but a clear difference between metabolic products and between the patients in group I and group II. Effects of glucose were not detectable by factorial analysis because the absence of an effect on the formation of glyceride-glycerol counterbalanced the clear effect.

Some effects of $\mathrm{pH}$ and bicarbonate concentrations in vitro on the metabolism of pyruvate by fat are shown in Tables V and VI and Fig. 1a-c. The incorporation of radioactivity into fatty acids, glyceride-glycerol, and $\mathrm{CO}$, for the two dietary regimes is presented as a function of $\mathrm{pH}$ using the data from the three patients in group II. Fat from each individual was subjected to 12 different incubation conditions, as shown in Table II. The incorporation of radioactivity into fatty acids and glyceride-glycerol was significantly increased $(P$ $<0.001$ ) by gorging. Dietary intake, however, had no significant effect on the conversion of radioactivity to $\mathrm{CO}_{2}$. These data were analyzed further by comparing the formation of metabolic products as a function of the concentration of bicarbonate (Fig. 1a-c). Gorging significantly enhanced the incorporation of radioactivity into glyceride-glycerol (Fig. 1b) and fatty acids (Fig. 1c). Bicarbonate, however, had no significant effect on the oxidation of pyruvate to $\mathrm{CO}_{2}$ (Fig. 1a) and 
of Data from Four Experiments*

\begin{tabular}{ccccccc}
\hline & Data from Fig. 1 b & & & \multicolumn{3}{c}{ Data from Fig. 1 c } \\
\cline { 6 - 7 } \multicolumn{1}{c}{ Factor } & Level & $P$ & & Factor & Level & $P$ \\
\hline Food intake & Nibbling & $<0.05$ & & Food intake & Nibbling & $<0.05$ \\
& Gorging & & & & Gorging & \\
Diet order & $\mathrm{N} \rightarrow \mathrm{G} \ddagger$ & $<0.05$ & & Diet order & $\mathrm{N} \rightarrow \mathrm{G}$ & N.S. \\
& $\mathrm{G} \rightarrow \mathrm{N}$ & & & & $\mathrm{G} \rightarrow \mathrm{N}$ & \\
Bicarbonate, $m M$ & 10 & $<0.05$ & & Bicarbonate, $m M$ & 10 & $<0.05$ \\
& 25 & & & 25 & Pco,$m M$ \\
$\mathrm{pCO}_{2}, m M$ & 20 & $<0.05$ & & & 20 & N.S. \\
& 40 & & & & 40 & \\
\hline
\end{tabular}

there was little difference between the $\mathrm{CO}_{2}$ evolved in either dietary regime. Decreasing the concentration of bicarbonate significantly decreased the conversion of pyruvate into glyceride-glycerol. Using factorial analysis with bicarbonate concentrations of 25 and $10 \mathrm{~mm} \mathrm{Hg}$ (Table IV, third comparison) and $\mathrm{Pco}_{2}$ of 40 and 20 $\mathrm{mm} \mathrm{Hg}$ (Table IV, right hand column), the conversion of radioactivity from pyruvate into glyceride-glycerol or fatty acids was reduced by low concentrations of bicarbonate or a low $\mathrm{Pco}_{2}$. These effects were not, however, due to the corresponding changes in $\mathrm{pH}$ (see Table VI). Gorging significantly increased the formation of glyceride-glycerol (Table IV, third column from the left) and fatty acids (Table IV, right hand column). The order in which the diets were fed also influenced the production of glyceride-glycerol (Table IV) but not fatty acids.

Ethoxzolamide, a carbonic anhydrase inhibitor, reduced the incorporation of radioactivity into all three products (Table VII). The formation of fatty acids, glyceride-glycerol, and $\mathrm{CO}_{2}$ was inhibited to a similar degree at all concentrations of bicarbonate (Table VII). Diet had no effect.

Metabolism of citrate and acetate. The conversion of carbon from acetate and citrate into fatty acids by adipose tissue from the patients in group II is shown in Table VIII. Significant amounts of radioactivity from citrate appeared as fatty acids after incubation of fat from both dietary regimes. Radioactivity from acetate was also readily converted to fatty acids. No dietary effects were evident.

Effects of diet on enzymatic activity. Enzymatic activities from adipose tissue are presented in Table IX where data from groups I and II are shown separately and combined. There was a two-fold increase in the activity of sn-glycerol 3-phosphate dehydrogenase in the adipose tissue from patients who were gorging (Table IX). The direction of this change is consistent with the increase in the incorporation of radioactivity into glyceride-glycerol by adipose tissue obtained after gorging (Table IV and Fig. $1 \mathrm{~b}$ ). The activity of mitochondrial glycerophosphate oxidase was more active in the adipose tissue from the patients in group II while gorging. In addition, the activity of this enzyme was significantly higher in the adipose tissue from the patients in group II as compared to those in group I. The activity of glucose-6-phosphate dehydrogenase, malic enzyme, malate dehydrogenase, and lactate dehydrogenase, on the other hand, was not significantly influenced by the dietary regimes. Finally, the activity of malic enzyme and glucose-6-phosphate dehydrogenase was higher in group II during the nibbling periods than in the comparable period in group I.

\section{DISCUSSION}

The present experiments are in harmony with several studies showing that the frequency of meals may be related to lipid metabolism in man and in rats. Cohn (14) observed that serum cholesterol was reduced when the same amount of food was eaten in several small meals, as compared to a few large meals. A reduction in cholesterol of subjects eating many small meals has also been noted by Gwinup, Byron, Roush, Kruger, and Hamwi (15), Jagannathan, Connell, and Beveridge (16), and Irwin and Feeley (17). Frequent, small meals also tend to improve glucose tolerance $(7,18)$. Fabry, Fodor, Hejl, Braun, and Zvolankova, who surveyed 379 men aged 60-64, observed that excess weight, hypercholesterolemia, impaired glucose tolerance, and skin fold thickness were greatest in the men who ate the fewest meals (7). A study by Fabry, Hejda, Cerny, Osancova, and Pechar (19) of the height/weight ratio 

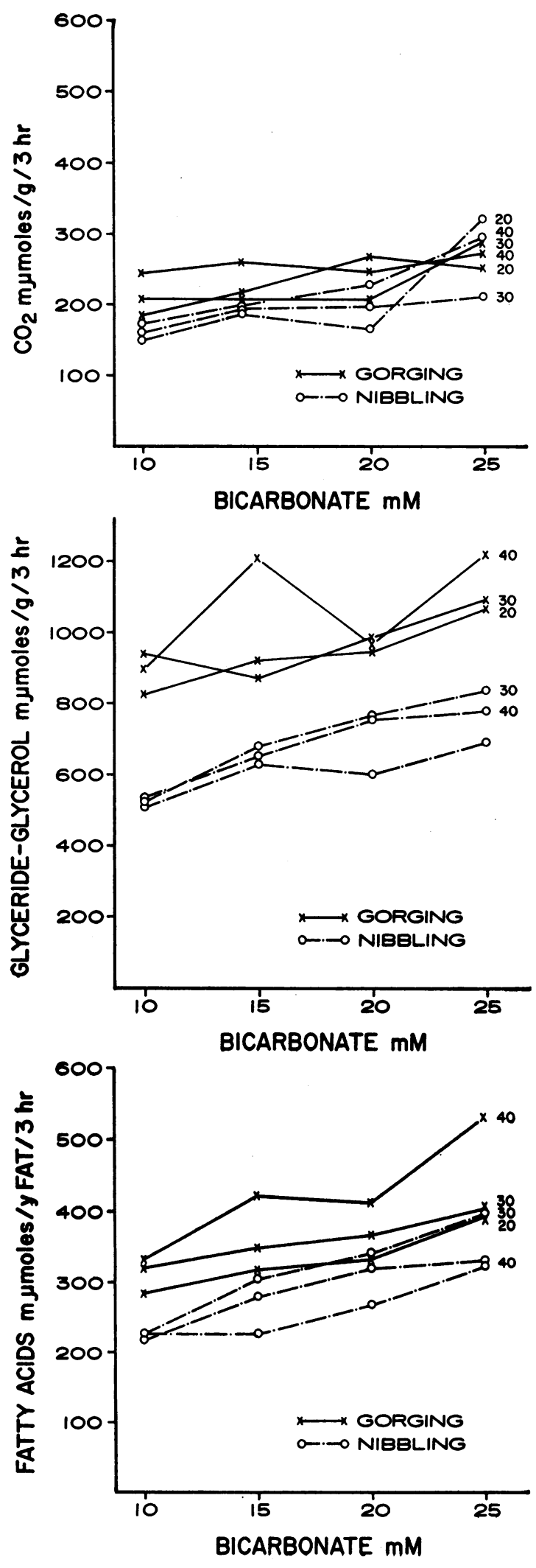

542 of children in schools that served three, five, or seven meals showed a tendency to excess weight in the children aged 10-16 who were eating three meals. In contrast to these effects on lipids, weight loss is not significantly influenced by feeding one, three, or nine meals (20). Meal size, likewise, does not influence the excretion of nitrogen, calcium, magnesium, or phosphorus, nor the digestibility of fat $(17,21,22)$.

In the rat, meal-eating or gorging likewise produces alterations in lipid metabolism (4). After a period of adaptation, the meal-eating rats gained weight at the same (2) or greater rate (5) as nibbling controls, although food intake was only $75-80 \%$ as much. This implies that the efficiency of food utilization, defined as the weight gained per gram of food eaten, is higher in meal-eating rats. In the experiments reported by Leveille (2), nibbling rats gained $0.0972 \mathrm{~g} / \mathrm{g}$ of diet compared to 0.1275 for meal-eating rats. Further support for the concept that enhanced efficiency accompanies gorging has come from experiments with pairfed rats (1) and studies on obesity (23). When mealeating rats are tube-fed to provide the same food intake as nibbling controls, they accumulate more fat $(1,24$, $25)$. After the rapid ingestion of food, the $R Q$ of meal-fed rats may rise above 1 , indicating rapid conversion of carbohydrate to fat (26).

Detailed examination of the metabolic pathways in adipose tissue from meal-eating rats has revealed a number of significant changes which are shown with heavy arrows in Fig. 2a (reproduced with permission from G. A. Leveille [2]). In general, the pathways for generating NADPH and for converting pyruvate and acetate to fatty acids show increased enzymatic activity. For comparison, Fig. $2 \mathrm{~b}$ shows the pathways (heavy arrows) where changes were observed in the present studies. The activity of enzymes in the pathways for generating NADPH were unchanged. The activity of sn-glycerol 3-phosphate dehydrogenase in human fat, however, was probably increased. One major difference from the animal data is that our studies were performed on obese subjects. The data in Fig. 2a were obtained with lean animals and whether obese animals would show the same pattern and degree of adaptive hyperlipogenesis (4) is not clear.

Figure 1 Effect of bicarbonate concentration on the metabolism of pyruvate by adipose tissue. Adipose tissue was incubated in triplicate with $5 \mathrm{~mm}$ pyruvate- $-3{ }^{14} \mathrm{C}$ and $5 \mathrm{~mm}$ glucose in a medium containing $150 \mathrm{~mm}$ sodium and a bicarbonate and chloride concentration of $145 \mathrm{mM}$. Albumin was present at $40 \mathrm{mg} / \mathrm{ml}$. The $\mathrm{pH}$ was adjusted according to the plan in Table II. Fig. 1 a shows the formation of $\mathrm{CO}_{2}$, Fig. 1b shows the radioactivity in glyceride-glycerol, and Fig. 1c shows the radioactivity in fatty acids. Each point is the mean for the three patients in group II. Statistical analysis is shown in Table IV. 
TABLE V

Metabolism of Pyruvate by Adipose Tissue from Obese Subjects*

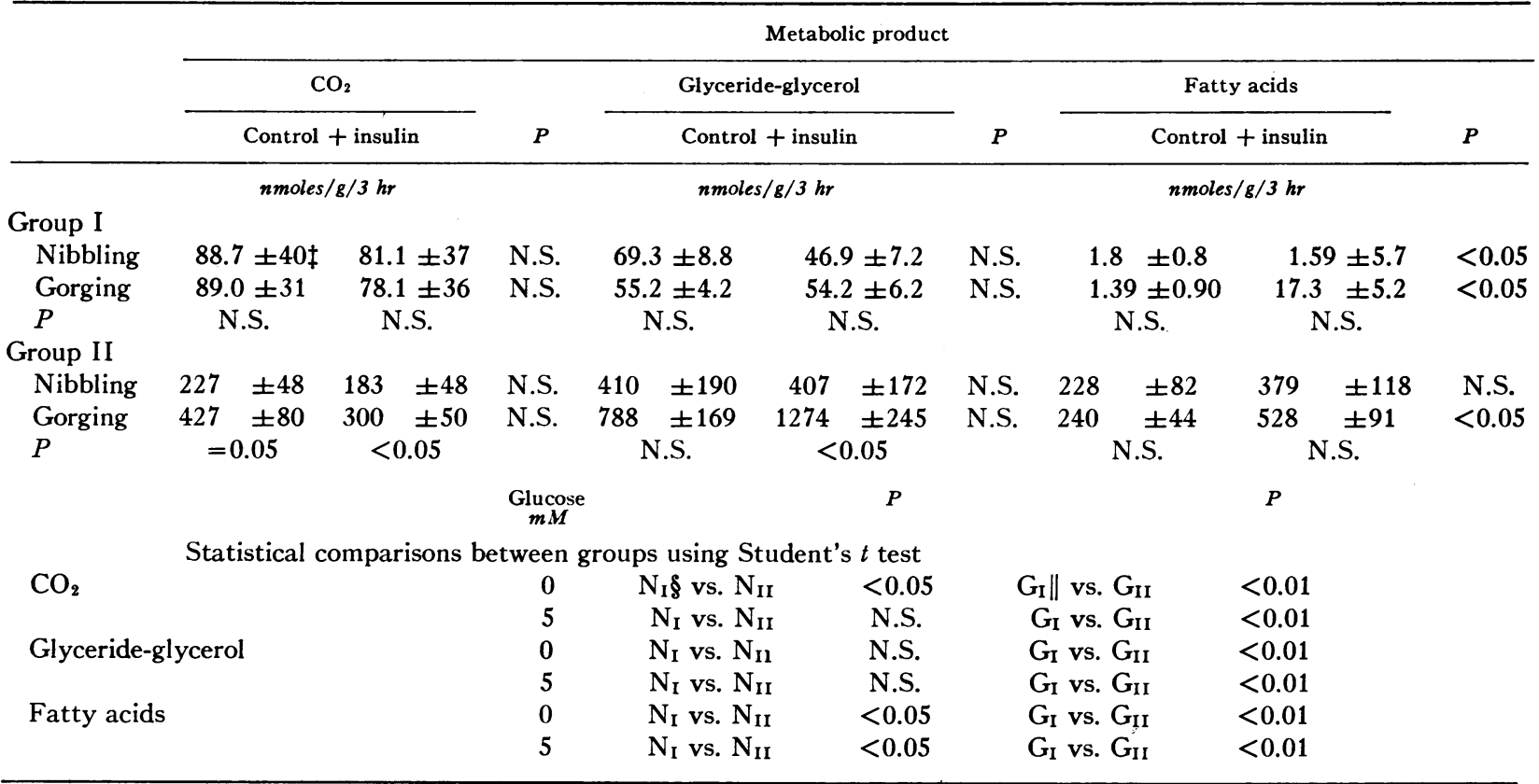

* Pieces of fat were incubated in triplicate in Krebs-Ringer bicarbonate buffer containing

$5 \mathrm{~mm}$ pyruvate- $3-{ }^{14} \mathrm{C}$ and albumin $40 \mathrm{mg} / \mathrm{ml}$.

$\ddagger$ Mean \pm se.

$\S \mathrm{N}$, Nibbling; the subscript I or II represents the group.

$\| \mathrm{G}$, Gorging; the subscript I or II represents the group.

The preceding paragraphs have summarized data which show that when food is ingested rapidly, it is stored more efficiently than when the same food is eaten over a longer period of time. The basis for this efficiency is unclear but two possibilities appear most likely: (a) that activity or energy output of the mealeating animals drops, or $(b)$ that efficiency of biological oxidations is increased. The glycerophosphate cycle has been proposed as one mechanism by which metabolic efficiency might be modulated $(8,27)$. In this cycle, hydrogens are transferred from extramitochondrial pyridine nucleotides to intramitochondrial flavine nucleotides. This transfer short-circuits one of the steps for generating ATP within the mitochondrion. Thus, a pair of hydrogens oxidized via the glycerophosphate cycle would yield 2 moles of ATP as opposed to 3 moles of ATP during the oxidation of $\mathrm{NADH}$ within the mitochondrion. Increased flow of hydrogen over the glycerophosphate cycle would be expected to reduce the formation of ATP. If increased metabolic efficiency were modulated by changes in this cycle, one would expect gorging to reduce the activity of the mitochondrial glycerophosphate oxidase which is the rate-limiting step. Contrary to expectation, the activity of the mito- chondrial enzyme increased with gorging in groups I and II (Table IX). Such a change makes it difficult to assign a role as a modulator of metabolic efficiency to the glycerophosphate cycle. The function of this cycle is thus unknown and the interpretation of the alterations observed with thyroid hormone (8) is unclear. Fat from the patients in group II had significantly higher levels of the glycerophosphate oxidase than fat from patients in group I. It has been reported previously that obesity is associated with low levels of this enzyme (28). With weight loss, however, the levels of this enzyme increased and were comparable to those in well-nourished lean subjects (Table IX). This suggests that the diminished activity of the glycerophosphate cycle is secondary to obesity and not its cause.

The role of human adipose tissue as a site for the synthesis of long-chain fatty acids is still unsettled. In a recent paper entitled "Comparative Aspects of Lipogenesis in Mammalian Tissues," the authors concluded that ". . . fatty acid biosynthesis de novo does not occur in human adipose tissue" (29). Several lines of evidence are used to support this hypothesis. First, the activity of several key enzymes in human adipose tissue showed little or no adaptation with fasting or refeed- 
TABLE VI

Effect of $p H$ on Metabolism of Pyruvate by Adipose Tissue from Obese Subjects*

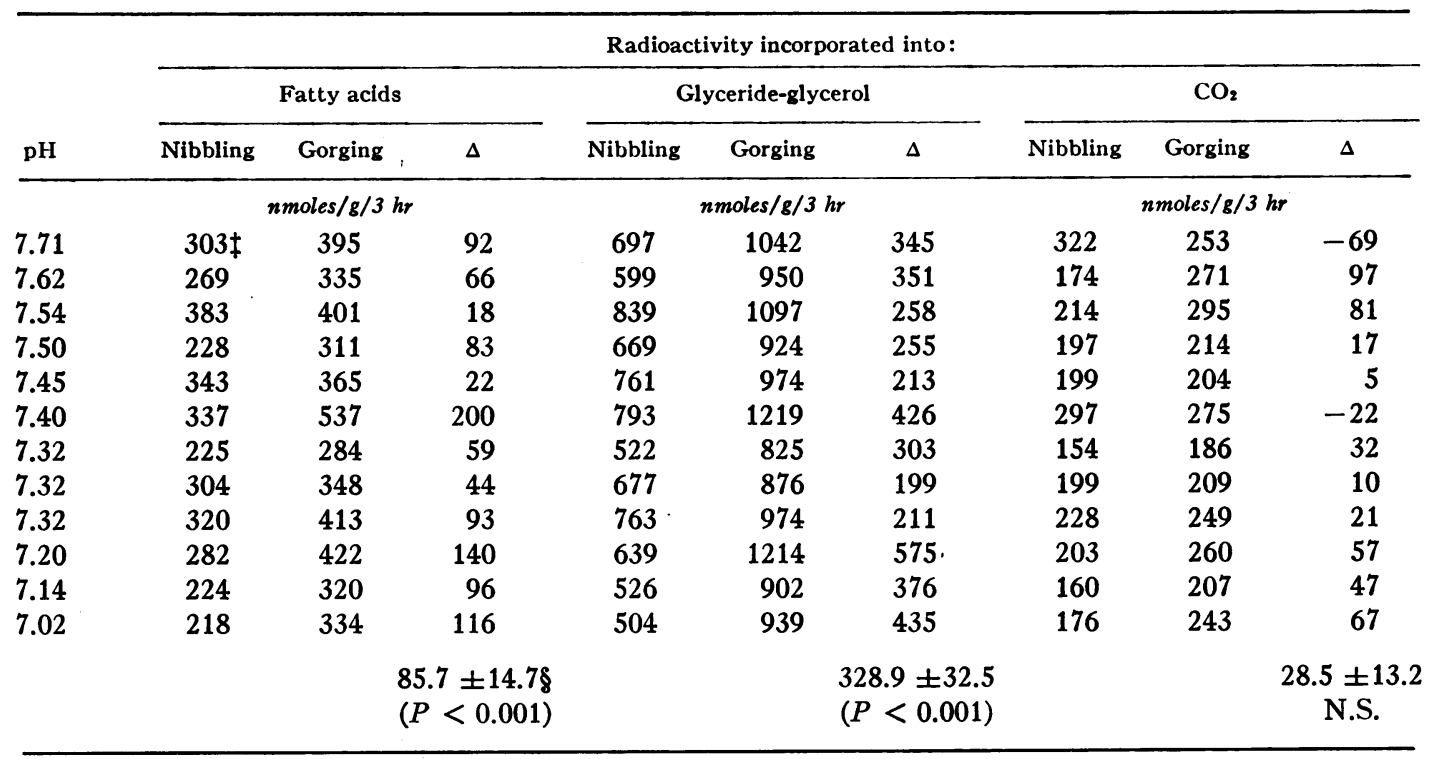

* Triplicate incubations at each $\mathrm{pH}\left(\mathrm{PCO}_{2}-\mathrm{HCO}_{3}\right.$ combination) were carried out with adipose tissue from each biopsy. The values represent the mean for the patients in group II.

$\ddagger$ Mean for the three patients.

$\S$ Mean \pm SEM.

ing (30). Second, there was a very low rate for transfer of glucose carbons into long-chain fatty acids in human adipose tissue (31-36). Third, the activity of the citrate cleavage enzyme (citrate lyase), a key step in the regulation of lipogenesis in fat, is very low in human adipose tissue $(29,37)$. The experiments reported in the present communication suggest the need for a critical reevaluation of the evidence underlying this hypothesis.
The levels of lipogenic enzymes reported by Shrago, Glennon, and Gordon (30) are similar to the data presented in Table IX. Like Shrago et al. (30), we failed to observe significant changes in the activity of these enzymes during overfeeding in either group I or group II. Yet, significantly more radioactivity from pyruvate was incorporated into fatty acids by fat from patients in group II than group I (Table V and Table VI). This contrast between enzymatic activity on the

TABLE VII

Effect of Ethoxzolamide on the Metabolism of Pyruvate*

\begin{tabular}{|c|c|c|c|c|c|c|}
\hline \multirow{3}{*}{$\begin{array}{l}\text { Bicar- } \\
\text { bonate }\end{array}$} & \multicolumn{6}{|c|}{ Inhibition } \\
\hline & \multicolumn{2}{|c|}{ Fatty acids } & \multicolumn{2}{|c|}{ Glyceride-glycerol } & \multicolumn{2}{|c|}{$\mathrm{CO}_{2}$} \\
\hline & Nibbling & Gorging & Nibbling & Gorging & Nibbling & Gorging \\
\hline$m M$ & \multicolumn{2}{|c|}{$\%$} & \multicolumn{2}{|c|}{$\%$} & \multicolumn{2}{|c|}{$\%$} \\
\hline 25 & 28 & 36 & 27 & 28 & 44 & 32 \\
\hline 20 & 32 & 10 & 33 & 0 & 29 & 9 \\
\hline 15 & 44 & 30 & 34 & 25 & 25 & 38 \\
\hline \multirow[t]{2}{*}{10} & 41 & 37 & 37 & 33 & 31 & 31 \\
\hline & $36.2 \pm 3.0$ & $28.2 \pm 7.2$ & $32.8 \pm 2.4$ & $21.5 \pm 8.5$ & $32.2 \pm 4.7$ & $27.5 \pm 7.3$ \\
\hline
\end{tabular}

* Tissues were incubated in triplicate in buffer containing $150 \mathrm{~mm} \mathrm{Na}$ and a bicarbonate plus chloride of $145 \mathrm{mM}$ with or without ethoxzolamide $25 \mathrm{~g} / \mathrm{ml}$.

$\ddagger$ Mean \pm SEM. 
one hand and substrate utilization on the other suggests that lipogenesis in human adipose tissue may be controlled by mechanisms other than changes in the activity of these selected enzymes.

Most investigators have found that when human adipose tissue is incubated in vitro with radioactively labeled glucose over $90 \%$ of the radioactivity appears in the glyceride moiety and only $2-4 \%$ in fatty acids $(31,33,36)$. Insulin enhanced the oxidation of glucose to $\mathrm{CO}_{2}$ in many studies $(32-35,38,39)$, but stimulated incorporation of glucose carbon to fatty acids in fewer cases $(8,40-43)$. In contrast, over $50 \%$ of the radioactivity from glucose can appear in fatty acids when adipose tissue from rats is incubated in vitro (44). Almost without exception the human studies have used fat obtained from adults undergoing surgical operations. Such individuals are usually in negative or zero caloric balance. Since fasting inhibits lipogenesis (8), one would not expect to find much lipogenesis in fat obtained under these conditions. However, when adipose tissue from patients in positive caloric balance is examined, one can readily demonstrate the conversion of carbons from glucose or pyruvate into fatty acids $(8,27)$. Moreover, there is a positive correlation between lipogenesis from glucose and the activity of the pentose cycle (41). Whether this lipogenesis represents de novo synthesis of fatty acids or chain elongation of already existing fatty acids is unknown. Since lipogenesis in human fat is modified by dietary status (fasting vs. feeding; nibbling vs. gorging), we are led to the conclusion that during positive caloric balance human adipose tissue can serve as a site for the de novo synthesis of fatty acids. From the data on group II we can calculate that $50 \mathrm{~kg}$ of adipose tissue could contribute more than $25 \mathrm{~g}$ of fatty acids daily. This is
TABLE VIII

Conversion of Radioactivity from Citrate and Acetate to Fatty Acids*

\begin{tabular}{ll}
\hline & \multicolumn{2}{c}{ Radioactivity in fatty acids } \\
\cline { 2 - 2 } Citrate $\quad$ Acetate \\
\hline Nibbling & $11.4 \pm 4.0 \quad 340 \pm 101$ \\
Gorging & $16.0 \pm 1.9 \quad 200 \pm 87$
\end{tabular}

* Adipose tissue was incubated in triplicate in Krebs-Ringer bicarbonate buffer with $10 \mathrm{~mm}$ citrate-1,5-14 $\mathrm{C}$ or $10 \mathrm{~mm}$ methylacetate-- $\mathrm{H}$ for $3 \mathrm{hr}$ at $37^{\circ} \mathrm{C}$.

$\ddagger$ Mean \pm SE for the patients in group II.

a significant fraction of the $300 \mathrm{~g}$ weight gain, some of which must surely have represented fluid retention (group II, patients 2 and 3 ).

The activity of citrate cleavage enzyme is low in human adipose tissue (37). This enzyme serves as the principal source of acetyl CoA for lipogenesis and its low activity has been a key argument in the hypothesis that human adipose tissue does not synthesize significant amounts of fatty acids. In our experiments, radioactivity from citrate, as well as glucose, pyruvate, and acetate, was incorporated into fatty acids. These are unlikely to represent methodologic errors from contamination with incubating substrate, since zero time incubation blanks were carried through all steps and did not differ for any of the substrates. Carbons from acetate and pyruvate were readily converted to fatty acids; glucose and citrate were utilized less well. If radioactivity from citrate appears in fatty acids, the pathway for this conversion needs to be delineated. Reexamination of the data presented by Shrago, Spennetta,

TABle IX

Effect of Nibbling and Gorging on Some Enzymes of Human Adipose Tissue

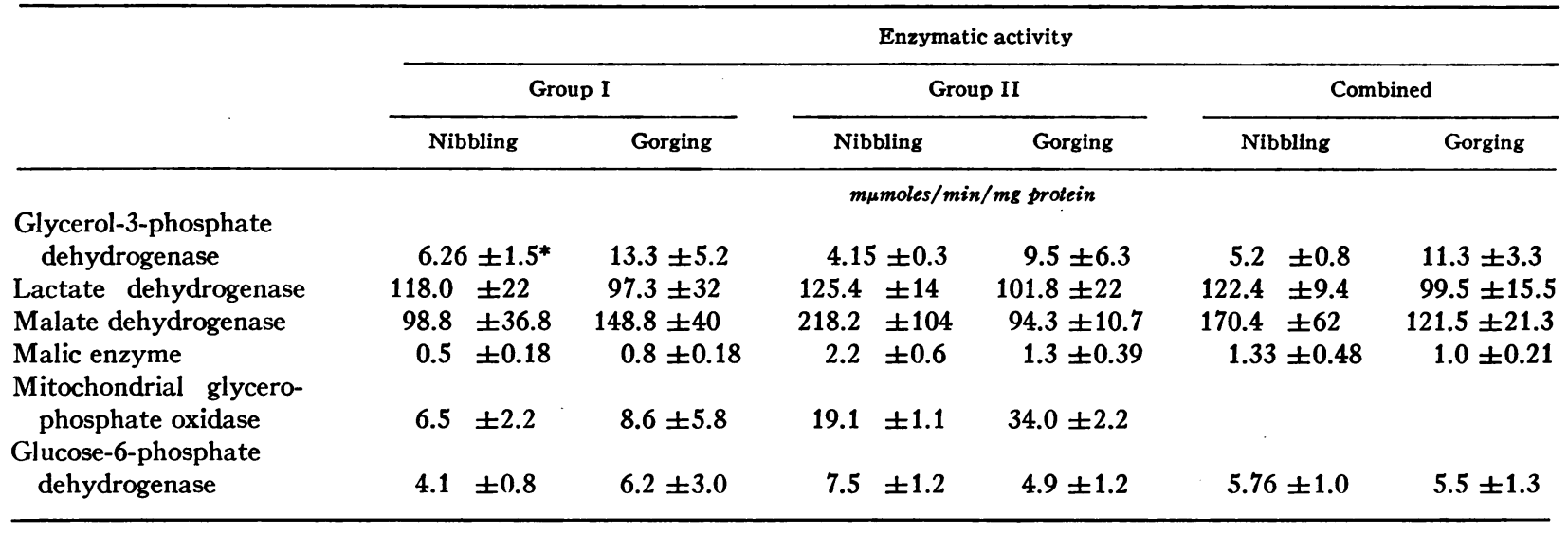

* Mean \pm SE. 

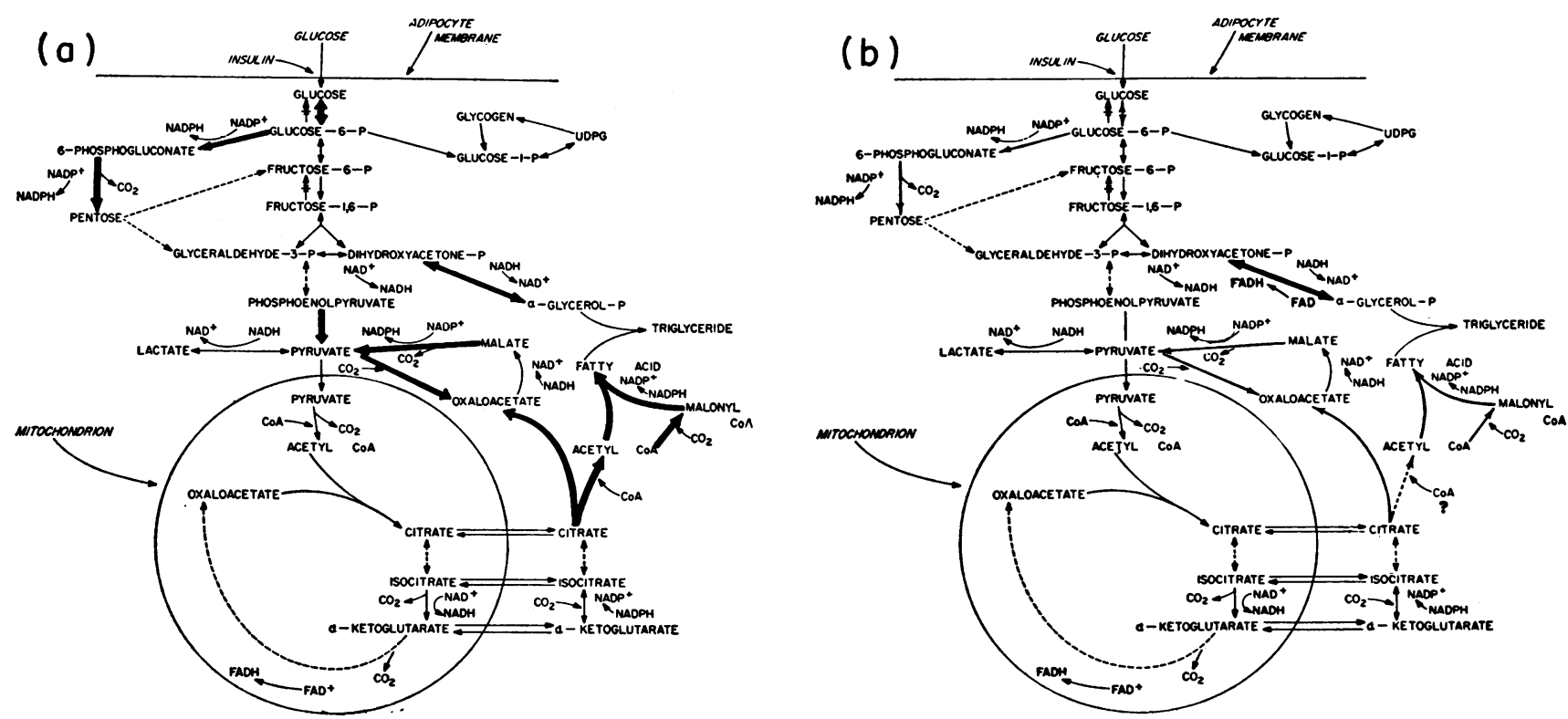

FIGURE 2 Metabolic pathways in adipose tissue. Fig. 2a shows with heavy arrows the pathways in rat adipose tissue which adapt to a gorging diet (reproduced with permission [2]). Fig. $2 \mathrm{~b}$ shows with heavy arrows the pathways in human adipose tissue which are altered with gorging.

and Gordon (37) indicates that approximately 5 nmoles of carbon from citrate/mg protein per hr were converted to fatty acids by an homogenate of human fat. The protein content of human fat is approximately 4 $\mathrm{mg} / \mathrm{g}$ and thus on the basis of his studies, 20 nmoles/g fat per $\mathrm{hr}$ could be incorporated into fatty acids. This value is comparable to the data reported in Table VIII. However, the activity of the citrate cleavage enzyme was only $2-4 \%$ of that required to account for these observed rates of citrate incorporation. There are two possible explanations for this discrepancy. The first is that carbon from citrate, pyruvate, and glucose are incorporated into fatty acids by pathways which do not require formation and cleavage of citrate. This possibility is supported by the observation that radioactivity from acetate was incorporated into fatty acids 20-30 times more rapidly than citrate (Table VIII) (37). A second possibility is that the assay conditions for citrate lyase which are appropriate for fat from rats do not measure the activity in human fat. In either case, the data suggest that human fat, like fat from rats, can synthesize fatty acids de novo.

Synthesis of fatty acids involves fixation of $\mathrm{CO}_{2}$ to acetyl CoA to form malonyl CoA which is then condensed to form palmitate $(29,45)$. Although there is no evidence for carbonic anhydrase in adipose tissue (46), it was found that carbonic anhydrase inhibitors could reduce the synthesis of fatty acids in vivo (47, 48). For this reason we tested the possibility that a carbonic anhydrase inhibitor could inhibit lipogenesis in human adipose tissue. There was a significant reduction in the formation of all metabolic products (Table VII), but nothing to suggest that pathways involving $\mathrm{CO}_{2}$ fixation had been affected selectively. There was also a significant inhibition of lipogenesis by lowering the concentration of bicarbonate. The lowest concentrations used in these experiments were just at the levels needed to show a reduction in fatty acid formation with homogenates (45).

\section{ACKNOWLEDGMENTS}

The author thanks Dr. T. F. Gallagher for assisting with some of the fat biopsies and Dr. E. B. Astwood for his support.

These studies were supported in part by grants from the National Institutes of Health, AM-9897, AM-5166, AM15165 , and RR-00425.

\section{REFERENCES}

1. Cohn, C., D. Joseph, L. Bell, and M. D. Allweiss. 1965. Studies on the effects of feeding frequency and dietary composition on fat deposition. Ann. N. Y. Acad. Sci. 131: 507 .

2. Leveille, G. A. 1970. Adipose tissue metabolism: influence of periodicity of eating and diet composition. Fed. Proc. 29: 1294.

3. Fabry, P., and J. Tepperman. 1970. Meal frequencya possible factor in human pathology. Amer. J. Clin. Nutr. 23 : 1059.

4. Tepperman, J. 1970. Gluconeogenesis, lipogenesis and the Sherringtonian metaphor. Fed. Proc. 29: 1284. 
5. Hollifield, G., and W. Parson. 1962. Metabolic adaptations to a "stuff and starve" feeding program. I. Studies of adipose tissue and liver glycogen in rats limited to a short daily feeding period. J. Clin. Invest. 41: 245.

6. Stunkard, A. J., W. J. Grace, and H. G. Wolff. 1955. The night-eating syndrome. A pattern of food intake among certain obese patients. Amer. J. Med. 19: 78.

7. Fabry, P., J. Fodor, Z. Hej1, T. Braun, and K. Zvolankova. 1964. The frequency of meals : its relationship to overweight, hypercholesterolemia, and decreased glucosetolerance. Lancet. $2: 614$.

8. Bray, G. A. 1969. Effect of diet and triiodothyronine on the activity of sn-glycerol-3-phosphate dehydrogenase and on the metabolism of glucose and pyruvate by adipose tissue of obese patients. J. Clin. Invest. 48: 1413.

9. Bray, G. A. 1960. A simple efficient liquid scintillator for counting aqueous solutions in a liquid scintillation counter. Anal. Biochem. 1 : 279.

10. Dole, V. P. 1956. A relation between non-esterified fatty acids in plasma and the metabolism of glucose. J. Clin. Invest. 35 : 150.

11. Bergmeyer, H. U., editor. 1965. Methods of Enzymatic Analysis. Academic Press Inc., New York.

12. Gornall, A. G., C. J. Bardawill, and M. M. David. 1949. Determination of serum proteins by means of the biuret reaction. J. Biol. Chem. $177: 751$.

13. Natrella, M. G. 1963. Experimental Statistics. U. S. National Bureau of Standards Handbook. No. 91. U. S. Government Printing Office, Washington, D. C.

14. Cohn, C. 1964. Feeding patterns and some aspects of cholesterol metabolism. Fed. Proc. 23: 76.

15. Gwinup, G., R. C. Byron, W. H. Roush, F. A. Kruger, and G. J. Hamwi. 1963. Effect of nibbling versus gorging on serum lipids in man Amer. J. Clin. Nutr. 13: 209.

16. Jagannathan, S. N., W. F. Connell, and J. M. R. Beveridge. 1964. Effects of gormandizing and semicontinuous eating of equicaloric amounts of formula-type high fat diets on plasma cholesterol and triglyceride levels in human volunteer subjects. Amer. J. Clin. Nutr. 15: 90.

17. Irwin, I. M., and R. M. Feeley. 1967. Frequency and size of meals and serum lipids, nitrogen and mineral retension, fat digestibility and urinary thiamine and riboflavin in young women. Amer. J. Clin. Nutr. 20: 816.

18. Gwinup, G. R., C. Byron, W. H. Roush, F. A. Kruger, and G. J. Hamwi. 1963. Effect of nibbling versus gorging on glucose tolerance Lancet. 2 : 165.

19. Fabry, P., S. Hejda, K. Cerny, K. Osancova, and J. Pechar. 1966. Effect of meal frequency in school children. Changes in the weight-height proportion and skinfold thickness. Amer. J. Clin. Nutr. 18: 358.

20. Bortz, W. M., A. Wroldsen, B. Issekutz, and K. Rodahl. 1966. Weight loss and frequency of feeding. $N$. Engl. J. Med. 274: 376.

21. Swindells, Y. E., S. A. Holmes, and M. F. Robinson. 1968. The metabolic response of young women to changes in the frequency of meals. Brit. J. Nutr. 22: 667.

22. Finkelstein, B., and B. A. Fryer. 1971. Meal frequency and weight reduction of young women. Amer. J. Clin. Nutr. 24: 465.

23. Bray, G. A., and D. York. 1971. Genetically transmitted obesity in rodents. Physiol. Rev. 51: 598.

24. Cohn, C., and D. Joseph. 1959. Changes in body composition attendant on force feeding. Amer. J. Physiol. 196: 965 .
25. Cohn, C., and D. Joseph. 1960. Role of rate of ingestion of diet on regulation of intermediary metabolism ("meal eating" vs. "nibbling"). Metab. (Clin. Exp.) 9: 492.

26. Tepperman, J., J. R. Brobeck, and C. N. H. Long. 1943. The effects of hypothalamic hyperphagia and of alterations in feeding habits on the metabolism of the albino rat. Yale J. Biol. Med. $15: 855$.

27. Bray, G. A. 1970. Metabolic and regulatory obesity in rats and man. Horm. Metab. Res. Suppl. 2: 175.

28. Galton, D. J., and G. A. Bray 1967 The metabolism of $\alpha$-glycerol phosphate in human adipose tissue. J. Clin. Endocrinol. Metab. $27: 1573$.

29. Shrago, E., J. A. Glennon, and E. S. Gordon. 1971. Comparative aspects of lipogenesis in mammalian tissue. Metab. (Clin. Exp.). 20: 54.

30. Shrago, E., J. A. Glennon. and E. S. Gordon. 1967. Studies on enzyme concentration and adaptation in human liver and adipose tissue. J. Clin. Endocrinol. Metab. 27: 679 .

31. Hirsch, J., and R. B. Goldrick. 1964. Serial studies on the metabolism of human adipose tissue. Lipogenesis and free fatty acid uptake and release in small aspirated samples of subcutaneous fat. J. Clin. Invest. 43: 1776.

32. Goldrick, R. B. 1967. Effects of insulin on glucose metabolism in isolated human fat cells. J. Lipid Res. 8: 581.

33. Kuo, P. T., L. Feng, N. N. Cohen, W. T. Fitts, Jr., and L. D. Miller. 1967. Dietary carbohydrates in hyperlipemia (hyperglyceridemia): hepatic and adipose tissue lipogenic activities. Amer. J. Clin. Nutr. 26: 116.

34. Owen, J. A., R. W. Lindsay, J. H. Gaskin, and G. Hollifield. 1967. Response of human adipose tissue to endogenous serum insulin-like activity in vitro. Metab. (Clin. Exp.). 16: 47.

35. Gries, F. A., and J. Steinke. 1967. Insulin and human adipose tissue in vitro: a brief review. Metab. (Clin. Exp.). 16: 693 .

36. Galton, D. J. 1968. Lipogenesis in human adipose tissue. J. Lipid Res. 9: 19.

37. Shrago, E., T. Spennetta, and E. Gordon. 1969. Fatty acid synthesis in human adipose tissue. J. Biol. Chem. $244: 2761$

38. Bjorntorp, P. 1966. Studies on adipose tissue from obese patients with or without diabetes mellitus. II. Basal and insulin-stimulated glucose metabolism. Acta Med. Scand. 179: 229.

39. Salans, B.. J. L. Knittle, and J. Hirsch. 1968. The role of adipose cell size and adipose tissue insulin sensitivity in the carbohydrate intolerance of human obesity. $J$. Clin. Invest. $47: 153$.

40. Goldrick, R. B., and J. Hirsch. 1964. Serial studies on the metabolism of human adipose tissue. II. Effects of caloric restriction and refeeding on lipogenesis and the uptake and release of free fatty acids in obese and non-obese individuals. J. Clin. Invest. 43: 1793.

41. Bjorntorp, P. 1967. Th effect of insulin in vitro on human adipose tissue from normal and diabetic subjects. Acta Med. Scand. 181: 389.

42. Goldrick, R. B., and G. M. McLoughlin. 1969. Lipolysis and lipogenesis from glucose in human fat cells of different sizes. J. Clin. Invest. 49: 1213.

43. Mellati, A. M., J. C. Beck, J. Dupre, and D. Rubinstein. 1970. Conversion of glucose to lipid by human adipose tissue in vitro. Metab. (Clin. Exp.). 19: 988.

44. Flatt, J. P., and E. G. Ball. 1965. Pathways of glucose metabolism II. In Handbook of Physiology, Section V. 
A. E. Renold and G. F. Cahill, Jr., editors. American Physiological Society, Washington, D. C. 273.

45. Gibson, D. M., E. B. Titchener, and S. J. Wahl. 1958. Studies on the mechanism of fatty acid synthesis. V. Bicarbonate requirement for the synthesis of long-chain fatty acids. Biochim. Biophys. Acta. 36: 376.

46. Maren, T. 1967. Carbonic anhydrase: chemistry, physiology and inhibition. Physiol. Rev. 47 : 595.
47. Rous, S., and P. Favarger. 1963. Recherches sur la synthèse des acides gras XIII. Influence de l'acetozolamide seul ou associé à l'insuline sur la synthèse in vivo des acides gras chez la souris. Helv. Chim. Acta. 46: 2586.

48. Favarger, P., and S. Rous. 1965. L'action de l'anhydride carbonique sur la synthèse des acides gras. Exposes Annu. Biochim. Med. 26: 31 . 